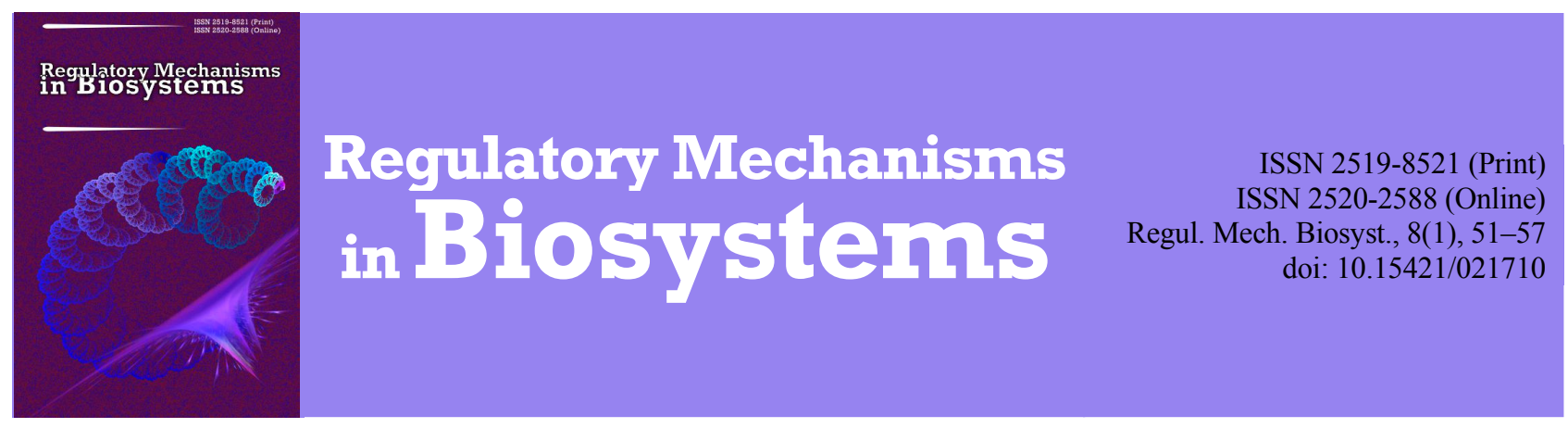

\title{
Coherence of EEG frequency components during manual movements executed by the subdominant hand in women
}

\author{
O. V. Korzhyk, O. S. Pavlovych, A. H. Morenko \\ Lesia Ukrainka Eastern European National University, Lutsk, Ukraine
}

Article info

Received 11.01.2017

Received in revised form 08.02.2017

Accepted 10.02.2017

Lesia Ukrainka

Eastern European

National University

Voli Ave., 13b,

Lutsk, 43000, Ukraine

Tel.: +38-066-826-27-23

E-mail:alevmore@gmail.com
Korzhyk, O. V., Pavlovych, O. S., \& Morenko, A. H. (2017). Coherence of EEG frequency components during manual movements executed by the subdominant hand in women. Regulatory Mechanisms in Biosystems, 8(1), 5157. doi: $10.15421 / 021710$

The academic community is paying more and more attention to the question of the individual characteristics of the brain processes which ensure the manual motor programming of movements performed not only by the leading, but also by the subdominant hand. Researchers do not exclude the existence of the particular parameters of the human brain correlating with manual motor activities. This study involved 136 women at the age of 19-21 years. The testees were divided into two groups according to high and low values of the EEG modal $\alpha$-frequency determined individually and in a motionless state. We evaluated the coherence status of the EEG frequency components in the motionless state and during movements performed by fingers of the subdominant (left) hand in response to rhythmic sound signals. The testing stages involved the sequential execution of motor tasks including clamping and unclamping performed by the fingers of the subdominant hand (such as grasping movements) without effort. The testees also performed fingering (a manual response to each stimulus) at in different times and not by all the fingers of the hand simultaneously, but separately, one by one, in a given sequence). Clamping and unclamping was executed by the fingers subject to power loading the (additional load on the fingers being $10 \mathrm{H})$. Execution of manual movements by means of the subdominant hand in response to the sensory signals was accompanied by an increase in coherence in the EEG frequency components, especially in the frontal, temporal, and parietal cortexes of the central areas. Women with a low individual $\alpha$-rate of such a regularity had significantly increased scores at the high $(\alpha 3-, \beta-)$ frequencies of the EEG spectrum. At the same time, women in both groups mainly showed a decrease in the coherence coefficients of $\theta$-, $\alpha 1$ - and $\alpha 3$-activity in the frontal cortex leads in terms of the execution of the sequential finger movements and movements under power loading. The analysis of differences proved that women with a low $\mathrm{I} \alpha \mathrm{F}$ had relatively higher coherence of the EEG frequency components in the frontal lobes. However, relatively higher frequency components of EEG coherence in the central, posterior temporal and parietal leads were set in women with high $\mathrm{I} \alpha \mathrm{F}$. Changes in cortical activity were established during different movements performed by fingers of the subdominant hand, namely, grasping movements of common occurrence, successive movements and movements under power loading. They differ from each other in their low specificity. Thus, the factor of motor performance of tests by means of the subdominant hand had obviously more decisive importance in the nature of the organization of brain activity than for the actual specifics of manual movements.

Keywords: individual $\alpha$-frequency; successive movements; power load; grasping movements

\section{Когерентність частотних компонентів електроенцефалограми під час виконання мануальних рухів субдомінантною рукою у жінок}

\author{
О. В. Коржик, О. С. Павлович, А. Г. Моренко
}

Східноєвропейський національний університет імені Лесі Українки, Луцькк, Україна

Обстежено 136 жінок віком 19-21 року, яких поділено на дві групи з високими та низькими значеннями модальної $\alpha$-частоти електроенцефалограми (ЕЕГ), визначеної індивідуально у стані спокою. Оцінювали показники когерентності частотних компонентів електроенцефалограми у стані спокою та під час стискання та розтискання пальців кисті (за типом хапальних рухів) без зусилля, почергових рухів пальців, стискання та розтискання пальців кисті із силовим навантаженням. Обстежувані виконували рухи пальцями кисті субдомінантної (лівої) руки у відповідь на ритмічні слухові сигнали. Виконання зазначених мануальних рухів у жінок обох груп загалом супроводжувало збільшення когерентності частотних компонентів ЕЕГ, особливо в лобових, скроневих, центральних і тім'яних кортикальних ділянках. Поряд із тим, за умови виконання почергових рухів пальців та рухів із силовим навантаженням у всіх жінок фіксували зменшення коефіцієнтів когерентності $\theta-, \alpha 1-$ i $\alpha 3$-активності, здебільшого у лобових відведеннях кори. У жінок із низькою І $\alpha Ч$ реєстрували вищу когерентність частотних компонентів ЕЕГ у лобових ділянках. Натомість у центральних, задніх скроневих та тім'яних відведеннях установлено порівняно вищу когерентність частотних компонентів ЕЕГ у жінок із високою І $\alpha$ Ч. Зміни кортикальної 
активності, встановлені під час виконання різних рухів пальців субдомінантної руки, як от звичних хапальних рухів, почергових рухів та рухів із силовим навантаженням, як правило, відзначалися низькою специфічністю.

Ключові слова: індивідуальна $\alpha$-частота; почергові рухи; силове навантаження; хапальні рухи

Вступ

Використання сучасних технічних засобів і технологій провокує підвищення вимог до функціональних можливостей сенсорної та моторної систем, діяльності головного мозку тієї чи іншої людини. Тому наукова спільнота (Averbeck et al., 2002; Hikosaka et al., 2002; Ioffe, 2003; Müller et al., 2003; Cisek, 2005; Ruge et al., 2014) приділяє все більшу увагу проблемі індивідуальних особливостей мозкових процесів, які забезпечують моторне програмування мануальних рухів (МР). Дослідники не виключають, що існують певні показники роботи головного мозку, які корелюють із мануальною моторикою.

Багато вчених (Kaplan and Borisov, 2003; Bazanova, 2008; Razumnikova et al., 2009; Umrjuhin et al., 2009) з'ясували, що індивідуальна варіативність амплітудно-частотних характеристик $\alpha$-ритму електроенцефалограми (ЕЕГ), зокрема модальна частота цього ритму, відзначаються високою інформативністю для визначення стану нервових процесів та низки психофізіологічних функцій людини. Для людей, які відрізняються характеристиками $\alpha$-ритму, характерні відмінні поведінкові стратегії, механізми сприйняття, переробки інформації (Hummel et al., 2004; Kristeva et al., 2005; Bazanova, 2008). Такі твердження грунтуються на тому, що модальну $\alpha$-частоту ЕЕГ вважають (Anderson et al., 2005; Page et al., 2006; Anokhin et al., 2006; Spergel, 2007) жорстко детермінованою генетичною ознакою, оскільки вона відображає важливі вроджені особливості структурної організації таламічних і кортикальних нейронів (Niswender et al., 2005; Smit et al., 2006; Bellone and Nicoll, 2007; $\mathrm{Ng}$ and Raveendran, 2007).

Визнаючи виняткову важливість отриманих різними вченими результатів, все ж слід підкреслити, що така інформація вочевидь недостатня для вичерпного розуміння того, як пов'язаний такий уроджений аспект функціонування мозку як модальна частота $\alpha$-ритму ЕЕГ із керуванням діяльністю дистальних м'язів руки під час виконання певних МР. У проведених раніше дослідженнях (Morenko et al., 2013; 2013; 2014) у контексті такої проблематики показано особливості мозкових процесів, які лежать в основі керування МР ведучої руки в жінок із різними вихідними характеристиками $\alpha$-ритму ЕЕГ, зокрема модальною частотою цього ритму. Відповідно до одержаних результатів осіб із вихідною високою модальною частотою $\alpha$-ритму ЕЕГ відзначався вищий рівень вибірковості уваги та локальніші зміни електричної активності кори головного мозку у перебігу регуляції мануальної моторики. Для осіб iз низькою $\alpha$-частотою притаманні менш специфічні та диференційовані процеси активації кори. Створення повноцінного уявлення про особливості мозкових процесів людини, пов'язаних із мануальною моторикою, передбачає дослідження останніх під час рухів пальців не лише ведучої, а й субдомінантної руки. Отже, в реальному житті людина під час мануальної моторики використовує як ведучу, так і субдомінантну руку. Тому мета цього дослідження - виявлення показників когерентності електричної активності кори головного мозку під час виконання жінками 3 різною вихідною модою альфа-частоти MP субдомінантною рукою. Застосування силового навантаження та зниження стереотипності завдання (під час перебирання пальців) - фактори, які ускладнюють як виконання, так i програмування МР у відповідь на дію певних сигналів. Вивчення когерентності частотних коливань ЕЕГ під час виконання різних МР дасть уявлення щодо характерних функціональних об'єднань кортикальних ділянок, безпосередньо пов'язаних із програмуванням МР субдомінантної руки. Мета цього дослідження - виявити особливості когерентності частотних компонентів електричної активності кори головного мозку під час виконання жінками МР субдомінантною рукою.

\section{Матеріал і методи досліджень}

Відповідність етичним стандартам. Комісія з питань біоетики Східноєвропейського національного університету імені Лесі Українки встановила (протокол № 1 від 18.10.2012), що всі обстеження проведені відповідно до основних біотичних норм Гельсінської декларації Всесвітньої медичної асоціації про етичні принципи проведення науково-медичних досліджень за участі людини (1964-2000), Декларації принципів толерантності (1995), Універсальної декларації з біоетики та прав людини (1997), Конвенції Ради Європи 3 прав людини та біомедицини (1997), наказу МОЗ України від 13.02.2006 р. № 66. Всі обстежувані давали письмову згоду для участі в експерименті. Вжиті необхідні заходи для забезпечення анонімності обстежуваних.

Об'єкт дослідження. У наших дослідженнях взяли участь 136 жінок у віці 19-21 рік: усі здорові, мають нормальний слух за даними медичного професійно-консультативного висновку. Під час формування контингенту до уваги брали й такі фактори як відсутність у тестованих черепно-мозкових травм в анамнезі, добрий стан самопочуття на час тестування, профіль мануальної та слухової асиметрій. Обстеження жінок проводили під час лютеїнової фази менструального циклу, оскільки рівень збудливості мозку в жінок залежить від впливу статевих гормонів. У пізню фолікулярну фазу нервова система більш збудлива, що спричинено естрогеном, а в лютеальну фазу, навпаки, загальний рівень збудливості головного мозку жінки найнижчий упродовж овуляційного циклу, оскільки в дію вступає прогестерон, який здійснює гальмівний вплив (Razumnikova et al., 2009).

Усі обстеження здійснювали в робочі дні тижня, у першій половині дня у два послідовні етапи - психофізіологічного та електроенцефалографічного тестувань. Експеримент проводили на базі навчально-наукової лабораторії вікової нейрофізіології кафедри фізіології людини та тварин Східноєвропейського національного університету імені Лесі Українки.

Психофізіологічне тестування. Час проведення такого тестування - до десяти хвилин. Профіль мануальної та слухової асиметрії визначали в кожної випробуваної за характером відповідей у ході опитування, виконання моторних і психоакустичних проб, за розрахунком коефіцієнтів мануальної та слухової асиметрії (К $\mathrm{K}_{\mathrm{ac}}$ ) (Zhavoronkova, 2007):

$$
\mathrm{K}_{a c .}=\frac{\Sigma_{n p .}-\Sigma_{\text {лів. }}}{\sum_{n p .}+\Sigma_{\text {лiв. }}} \times 100 \%,
$$

де $\Sigma_{\text {пр. }}$ - сума завдань, під час виконання яких домінує права рука (праве вухо), $\Sigma_{\text {лів. }}$ - сума завдань, під час виконання яких домінує ліва рука (ліве вухо). У подальшому обстеженні взяли участь жінки, коефіцієнти мануальної та слухової асиметрії котрих мали позитивне значення та були вищі 50\%. Загальна кількість таких жінок склала 113. Профіль асиметрії оцінювали за 30 хвилин до початку реєстрації ЕЕГ.

Електроенцефалографічне тестування. Під час ЕЕГ-експерименту обстежувані перебували у звуко- та світлонепроникній кімнаті, у положенні напівлежачи в кріслі з підголовником, із заплющеними очима. Передпліччя фіксували на підлокітниках. Перед початком запису тестована отримувала загальну інструкцію про хід експерименту.

Для кожної обстежуваної протокол експериментальної процедури реєстрації ЕЕГ включав такі послідовні етапи: стан функціонального спокою, стискання та розтискання пальців без зусилля (за типом хапальних рухів, один цикл стискання та розтискання за секунду), почергові рухи пальців (перебирання), стискання та розтискання пальців із силовим навантаженням. Під час перебирання пальцями мануальне реагування на кожний стимул обстежувані здійснювали не одночасно всіма 
пальцями кисті, а по-одному в черговості, визначеній безпосередньо перед тестуванням: вказівний - безіменний - середній мізинний пальці. Умови цього експерименту повідомляли обстежуваним безпосередньо перед початком проби. На етапі застосування силового навантаження обстежувані додатково утримували напівзігнутими пальцями навантаження 10 Н (1 кг). Обстежувані виконували рухи пальцями кисті субдомінантної (лівої) руки у відповідь на ритмічні слухові сигнали.

Таким чином, у ході експерименту створено різні експериментальні умови для виконання рухів пальців, які мали відмінне функціональне значення. Під час етапу стискання та розтискання пальців кисті без зусилля обстежувані виконували звичні мануальні дії за типом хапальних рухів. За умови тесту «Почергові рухи пальців» висувалися підвищені вимоги до індивідуальних можливостей обстежуваних раціонально розподіляти увагу між сенсорним сприйняттям і моторним реагуванням, перебудовувати моторну програму згідно з черговістю включення в роботу рухових одиниць м'язів різних пальців. Застосування силового навантаження створювало необхідність зосередження уваги під час утримання та фіксації пальцями кисті вантажу, подолання його ваги. Важливим фактором було те, що усі МР обстежуваним необхідно виконувати із дотриманням темпу пред'явлення звукових сигналів.

Як ритмічний сигнальний подразник для стискання та розтискання пальців кисті використовували низькочастотну фоностимуляцію. Під час фоностимуляції як стимули звучали ритмічні акустичні сигнали, що імітували барабанний бій (програмне забезпечення Finale 2006; частота $2 \mathrm{c}^{-1}$, загальна кількість стимулів у пробі - 80). Вибір відносно низької частоти фоностимуляції зумовлений тим, що саме така частота відповідає частотному діапазону виконання мануальних рухів, що вивчаються. А останній принципово зумовлений біомеханічними можливостями реалізації рухів дистальних частин руки. Інерційні властивості таких частин руки виключають можливості реалізації рухів із частотами, які перевищують $3 \mathrm{c}^{-1}$. Слухові сигнали подавали бінаурально за допомогою чотирьох акустичних колонок, які розміщували на відстані 1,2 м від обстежуваного. Тривалість кожного сигналу становила 120 мс, частотний діапазон - 220-235 Гц, гучність на виході колонок не перевищувала 55 дБ над порогом чутності (визначали за допомогою шумоміра DE-3301 № 050701882). Така організація фоностимуляції забезпечує комфортне для сприйняття звучання стимулів, відповідає санітарним нормам. Гучність звуку додатково регулювали індивідуально для кожного обстежуваного до досягнення комфортного рівня.

Між етапами для відпочинку обстежуваних і унеможливлення розвитку явищ монотонії робили перерву на 1 хвилину. Упродовж цього часу проводили інструктаж про їх дії в наступній експериментальній ситуації. Це давало змогу обстежуваним краще налаштуватися на виконання наступного завдання та мінімізувало вплив попереднього етапу на параметри ЕЕГ. Задля виключення крайових ефектів реєстрацію ЕЕГ під час усіх проб починали через 15 с після початку діяльності та припиняли за 5 с до їі завершення. ЕЕГ-тестування загалом тривало 15 хвилин.

Ресстрація та первинний аналіз електроенцефалографічних даних. Біоелектричну активність кори головного мозку вважали показником його інформаційних процесів. Її реєстрацію та первинний аналіз здійснювали за допомогою апаратно-програмних електроенцефалографічних комплексів «Нейроком», «Нейролаб» (ТУ У 33.1-02066769-001-2002, свідоцтво про державну реєстрацію № 6038/2007 від 26 січня 2007 року, сертифікат відповідності засобам вимірювальної техніки Державного комітету України з питань технічного регулювання та споживчої політики № UA-M1/2p-3641-2001, чинний до 18.04 .2014 р.). Виробник - науково-технічний центр радіоелектронних медичних приладів і технологій «ХАІ-Медіка» Національного аерокосмічного університету імені М. С. Жуковського «Харківський аерокосмічний авіаційний інститут». ЕЕГ відводили 3 поверхні шкіри 3 використанням стандартних методичних прийомів.
Активні електроди розміщували за міжнародною системою 10/20 у дев'ятнадцяти точках на скальпі; використовували лобові (Fp1, Fp2, F3, F4, F7, F8), центральні (C3, C4), скроневі (T3, T4, T5, Т6), тім'яні (P3, Р4), потиличні (O1, O2), сагітальні (Fz, Cz, Pz) відведення. Відведення з непарним індексом відповідали лівій півкулі, а $з$ парним - правій. Відведення монополярні: як референтні використовували вушні контакти A1 i А2. Для поліпшення якості запису використовували додаткові реферетні електроди), які встановлювали між передньолобовим і латеральнолобовим відведеннями (Ref), між правим та лівим передніми лобовими відведеннями (N, nazion). Для поліпшеної режекції ЕКГ-сигналу (електрокардіографічного сигналу) з ЕЕГ використовували систему реєстрації ЕКГ. Кардіосигнал реєстрували в другому ЕКГ відведенні.

Для відстеження функціонального стану та реакцій обстежуваних на стимули використовували вмонтовану в комплексну систему відеомоніторингу з інфрачервоним підсвічуванням. Реєстрували 40 с інтервали ЕЕГ під час кожної функціональної проби. Під час проведення Фур'є-реалізації епоха аналізу становила 4 с із 50\% перекриттям, частота дискретизації аналогового сигналу - 500 Гц, вхідний опір для синфазного сигналу - понад 100 МОм. Фільтри високих частот установлювали на рівні 45 Гц, низьких - 0,5 Гц. Напруга внутрішніх шумів, приведена до входу, не перевищувала 0,8 мкВ. Стала часу перехідного процесу становила не менше 0,3 с, коефіцієнт послаблення синфазних сигналів - не менше 140 дБ, опір електродів - близько 100 кОм. Під’єднання реєструвальної апаратури до ЕОМ (процеcop Intel Core TM 2 Duo CPU, звуковий пристрій Audio Device on Nigh Defnittion) здійснювали через USB/2 порт. Межі можливої відносної похибки під час вимірювання напруги та часових інтервалів ЕЕГ сигналів становили $\pm 5 \%$. Для режекції ЕЕГ-артефактів використовували процедуру ICA-аналізу (Independent Component Analysis, аналізу незалежних компонент). У подальшому фільтрували ICA-компоненти з артефактним сигналом із результуючої ЕЕГ. Під час фільтрації артефактів з ЕЕГ видаляли не більше п'яти артефактних ICA-компонент. У разі якщо окремі спалахи артефактної активності не вдавалося відфільтрувати за допомогою ICA-обробки, артефактні відрізки видаляли 3 нативної ЕЕГ у ручному режимі.

Використання когерентного аналізу ЕЕГ дає змогу оцінити рівень просторової синхронізації нейронних ансамблів різних відділів кори однієї або протилежних півкуль під час формування функціональних станів людини. Обчислення цієї функції дає можливість стверджувати існування постійних фазових відношень, схожих або синхронних потенціалів між двома ЕЕГ відведеннями. Постійність фазових відношень, тобто висока когерентність потенціалів, відображає тісний функціональний зв'язок між активністю досліджуваних ділянок кори головного мозку, функціональну координацію, часову координацію (Lurija, 2000; Sviderskaja, 2009; Zhavoronkova, 2009). Первинний аналіз когерентності електричної активності основних частотних компонентів ЕЕГ здійснювали за допомогою програмного забезпечення «Нейроком». Показники когерентності розраховували для всіх відведень і тестових ситуацій. Оцінювали когерентність ЕЕГ-осциляцій у між- і внутрішньопівкульових парах відведень. Аналізували зміни коефіцієнтів когерентності, білыших за 0,5.

У кожного обстежуваного в кожному відведенні ЕЕГ у стані спокою із заплющеними очима визначали моду спектральної потужності $\alpha$-ритму ЕЕГ. Ї̈ значення усереднювали за всіма відведеннями; отриману величину вважали індивідуальною $\alpha$-частотою обстежуваного (І $\alpha$ Ч, Гц) (Klimesch et al., 2007). В усіх жінок розраховували середнє значення такого показника. Прийняли умовний розподіл вибірки. Жінки, які мали менше значення I $\alpha Ч$, ніж середнє, увійшли до групи з низькою І $\alpha$ Ч. Жінки, які мали більше значення І $\alpha Ч$, ніж середнє, увійшли до групи 3 високою І $\alpha Ч$. Додатково в десяти обстежуваних визначили рівень сталості величини індивідуальної $\alpha$-частоти ЕЕГ у стані спокою за показниками п'яти реєстрацій у різні дні. Межі частотних субдіапазонів ЕЕГ визначали індивідуально за методи- 
кою Angelakis et al. (2004), Klimesch et al. (2007). У правий бік від І $\alpha$ З кроком 2 Гц відкладали верхню межу $\alpha 3$-субдіапазону. Вона відповідала нижній межі $\beta 1$ смуги. Зліва від піка 3 кроком у 2 Гц визначали нижню межу $\alpha 2-$, у 4 Гц - $\alpha 1$-, у 6 Гц $\theta$-частот. Відповідно до класичних уявлень визначали верхню межу $\beta 1$ - (25 Гц) і $\beta 2$ - (26-35 Гц) субдіапазонів.

Статистична обробка результатів. Для перевірки на нормальність розподілів числових даних у вибірках застосовано W-тест Шапіро - Уїлкоксона за допомогою програми Statistica 6.0. Оскільки розподіли наших даних звичайно були нормальними, розраховували середні значення $(\mathrm{M})$, стандартні відхилення $(\sigma)$ та величини похибки середнього $( \pm \mathrm{m})$. Обчислення значущих відмінностей (від $\mathrm{P}<0,05-<0,01)$ здійснювали, використовуючи параметричні тести, зокрема t-критерій Стьюдента для залежних вибірок (між тестами) та незалежних із рівними вибірками (між групами).

\section{Результати}

Оцінювання індивідуальної модальної частоти $\alpha$-ЕЕГ-активності та визначення індивідуальних меж субдіапазонів частотного спектра ЕЕГ в обстежуваних. Середнє значення модальної частоти $\alpha$-активності у вибірці жінок $-10,25 \pm 0,03$ Гц. Враховуючи згладжений характер (відсутність вираженого піка) гістограми значень індивідуальної $\alpha$-частоти (рис. 1) в об- стежуваних жінок здійснили умовний розподіл вибірки за середнім значенням модальної частоти $\alpha$-активності. Сформували дві групи: з високими значеннями $\mathrm{I} \alpha \mathrm{\Psi}(\mathrm{n}=59, \mathrm{I} \alpha \mathrm{\Psi} \geq 10,25$ Гц); iз низькими значеннями $\mathrm{I} \alpha Ч(\mathrm{n}=54, \mathrm{I} \alpha Ч<10,25$ Гц $)$.

Похибка середнього $( \pm \mathrm{m})$ для значень $\mathrm{I} \alpha$ за показниками п'яти реєстрацій фонової ЕЕГ у різні дні варіювала в обстежуваних у діапазоні від 0,003 до 0,024 . Такі результати свідчили про досить високу сталість величини I $\alpha$ в обстежуваних.

Когерентність ЕЕГ під час стискання та розтискання пальців кисті субдомінантної руки без зусилля у жінок із різною індивідуальною частотою $\alpha$-ритму. У жінок із високою та низькою індивідуальною $\alpha$-частотою у цих умовах фіксували збільшення когерентності всіх частотних діапазонів ЕЕГ у лобових, скроневих, центральних та тім'яних ділянках кори (з $\mathrm{P}<0,05-<0,01)$. Така закономірність мала найбільшу значущість у а2-субдіапазоні (рис. 2).

Когерентність ЕЕГ під час почергових рухів (перебирання) пальців кисті субдомінантної руки у жінок із різною індивідуальною частотою $\alpha$-ритму. У жінок із високою та низькою індивідуальною $\alpha$-частотою в цих умовах фіксували загалом збільшення когерентності всіх частотних діапазонів ЕЕГ у корі ( $\mathrm{P}<0,05-<0,01)$. Така закономірність мала найбільшу значущість у $\alpha 2-, \alpha 3$ - і $\beta$-субдіапазонах (рис. 3). Натомість у лобових ділянках у смузі $\theta$-, $\alpha 1-$ i $\alpha 3$-коливань фіксували зменшення значень когерентності в групах обстежуваних (iз $\mathrm{P}<0,05-<0,01$ ).

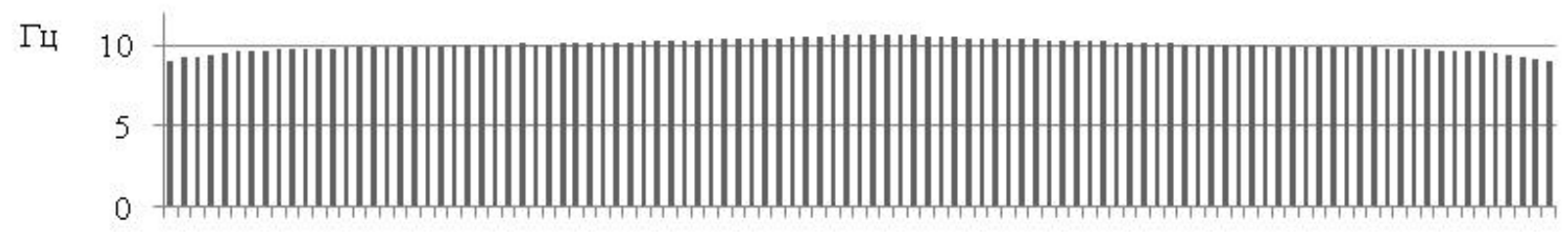

20

40

60

80

100

Вибірка обстеженихжінок

Рис. 1. Гістограма значень моди $\alpha$-частоти в обстежуваних жінок: вертикальні стовпчики - індивідуальні значення моди $\alpha$-частоти ЕЕГ в обстежуваних жінок

Жінки 3 високою $\mathrm{I} \alpha \mathrm{\Psi}$
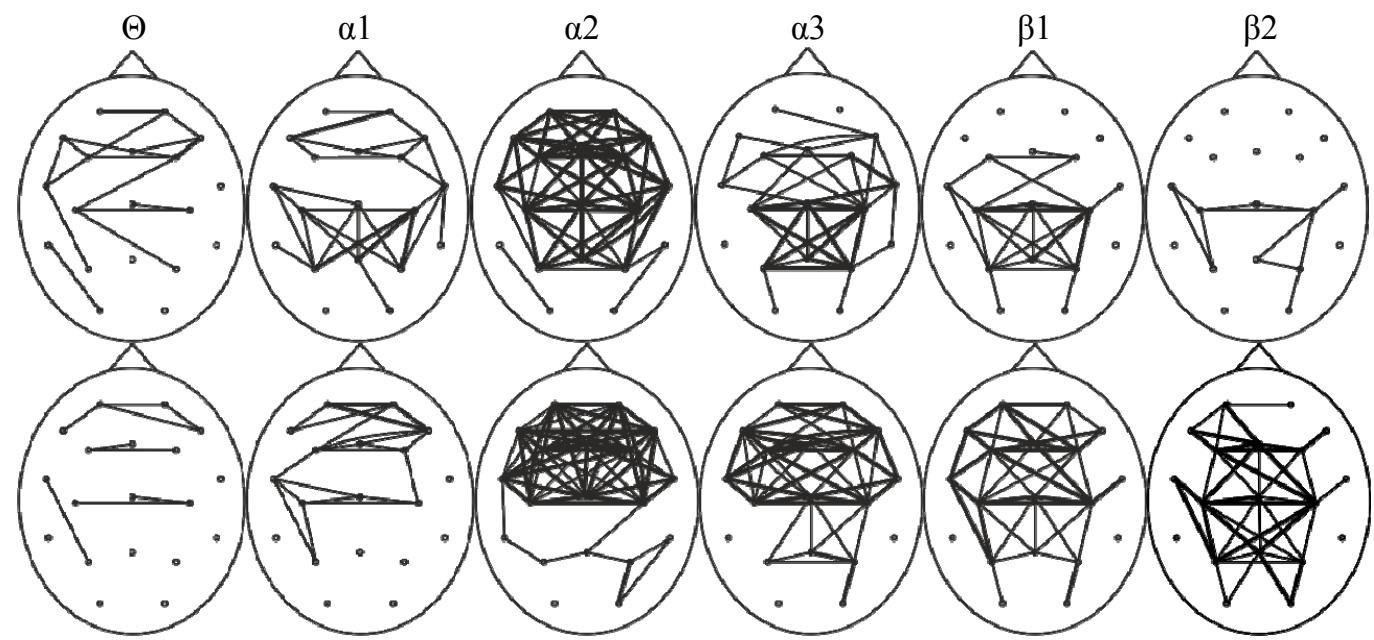

Рис. 2. Топокарти змін когерентності частотних компонентів ЕЕГ у групах жінок із різною індивідуальною частотою $\alpha$-ритму

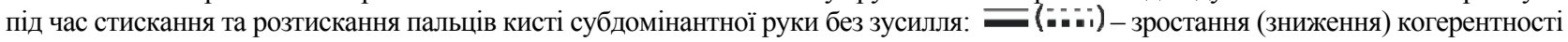
порівняно зі спокоєм, тонка риска $-\mathrm{P}<0,05$, товста риска $-\mathrm{P}<0,01$

Когерентність ЕЕГ під час стискання та розтискання пальців кисті субдомінантної руки із силовим навантаженням у жінок із різною індивідуальною частотою $\alpha-$ ритму. У жінок із високою індивідуальною $\alpha$-частотою в цих умовах фіксували збільшення когерентності частотних діапазонів ЕЕГ у ділянках кори (з $\mathrm{P}<0,05-<0,01)$ (рис. 4). Така закономірність мала найбільшу значущість у $\alpha 2-, \alpha 3-$ i $\beta$-субдіапазонах. Водночас, у жінок із високою I $\alpha Ч$ фіксували зменшення коефіцієнтів когерентності $\theta$ - i $\alpha 1$-активності у центральних ділянках кори $(\mathrm{P}<0,05)$, передусім справа, $\alpha 3$-коливань - у лобових відведеннях $(\mathrm{P}<0,05)$. Жінок із низькою I $\alpha Ч$ відзначало генералізоване зростання $\alpha 2$-, $\alpha 3$ - і $\beta$-когерентності коливань ЕЕГ у корі (з $\mathrm{P}<0,05-<0,01)$ (рис. 4). Натомість у діапазоні $\theta$ - і $\alpha 1$-активності реєстрували зменшення значень когерентності $(\mathrm{P}<0,05)$ в лобових, центральних та тім'яних ділянках. Такі зміни мали більш локальний характер. Зниження когерентності також установлювали у лобовій ділянці у $\alpha 3$-смузі. 


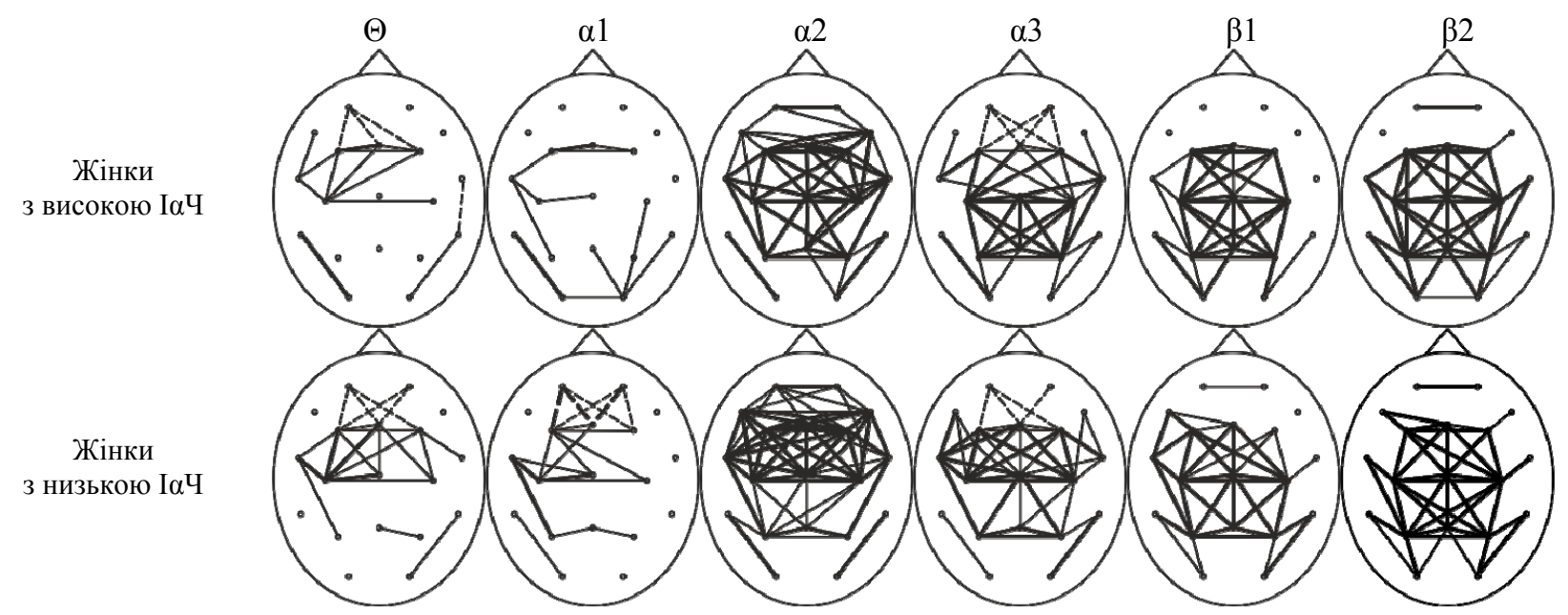

Pис. 3. Топокарти змін когерентності частотних компонентів ЕЕГ у групах жінок із різною індивідуальною частотою $\alpha$-ритму під час почергових рухів (перебирання) пальців кисті субдомінантної руки: позначення див. рис. 2

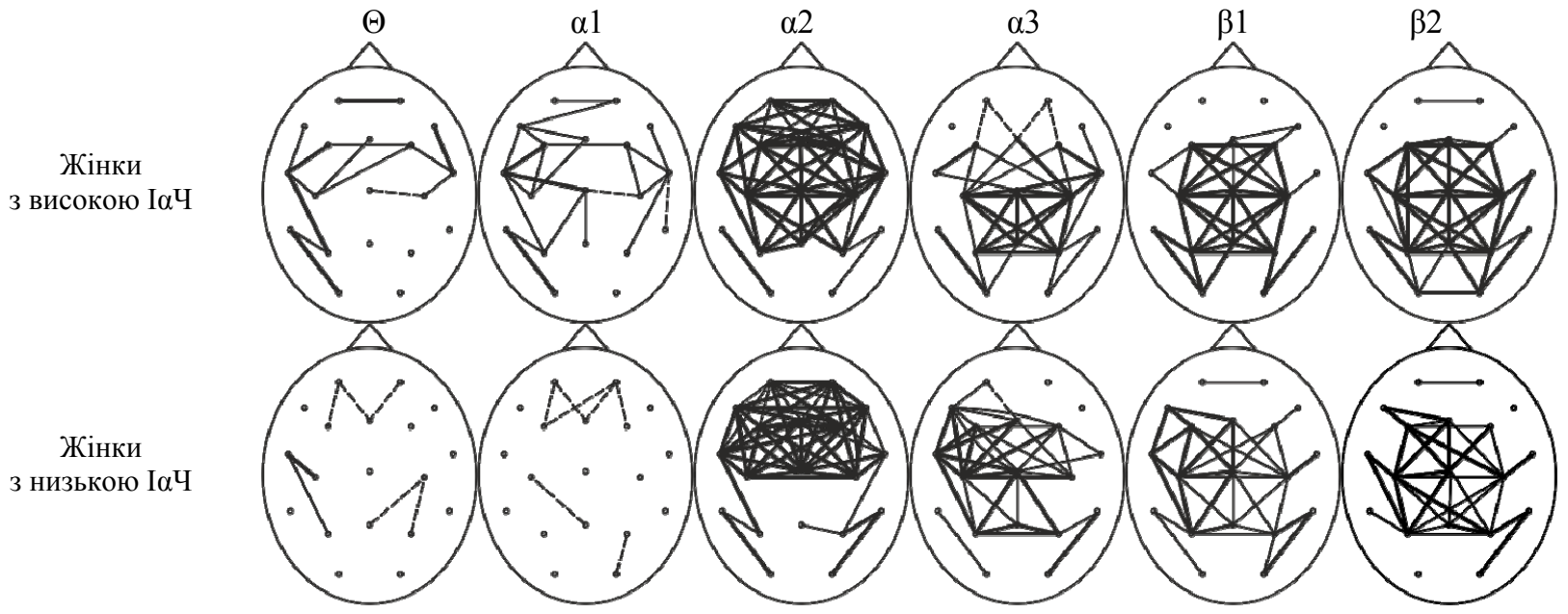

Pис. 4. Топокарти змін когерентності частотних компонентів ЕЕГ у групах жінок із різною індивідуальною частотою $\alpha$-ритму під час стискання та розтискання пальців кисті субдомінантної руки із силовим навантаженням: позначення див. рис. 2

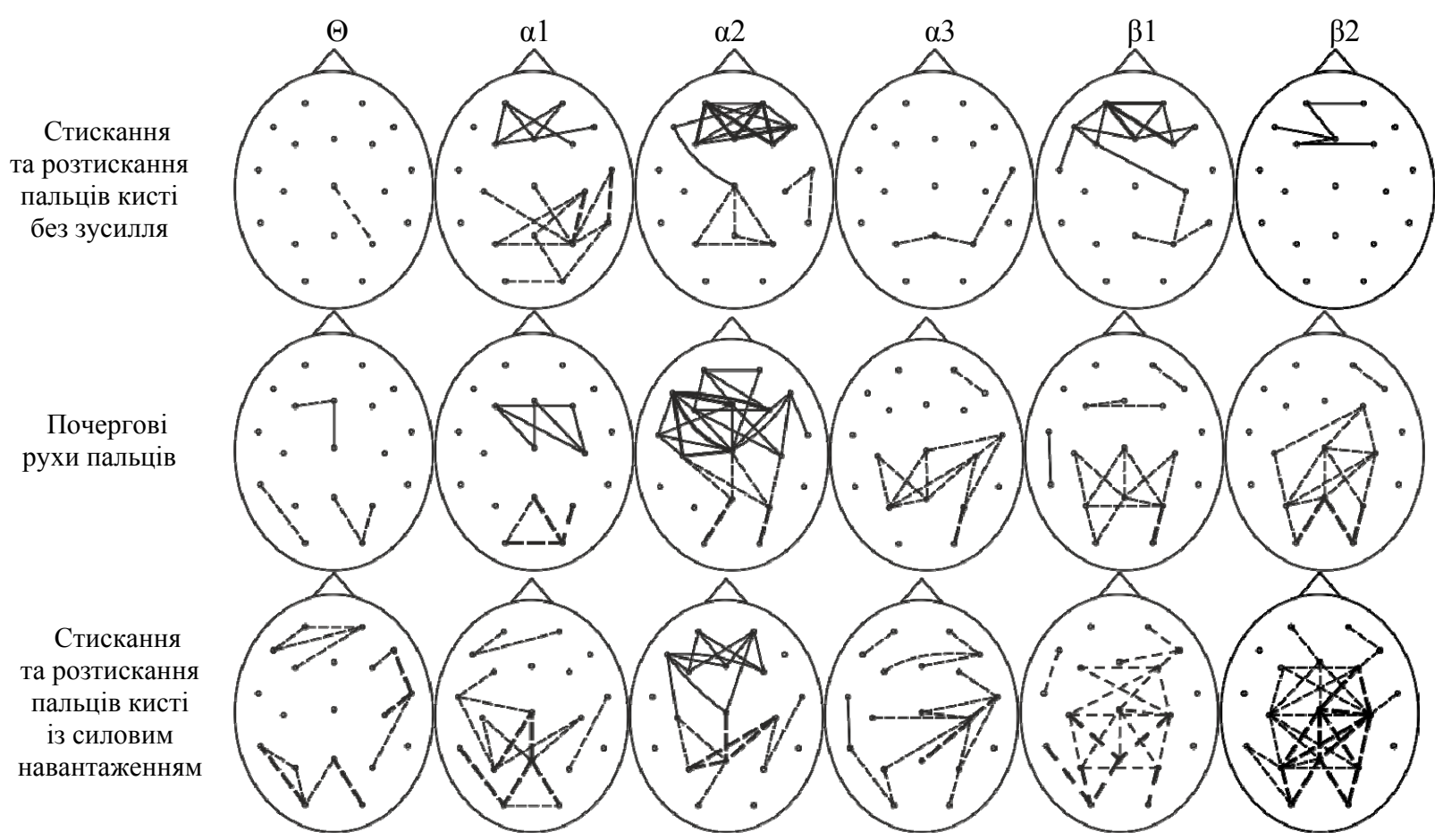

Рис. 5. Топокарти міжгрупових відмінностей когерентності частотних компонентів ЕЕГ під час виконання мануальних рухів у жінок із різною індивідуальною $\alpha$-частотою: позначення див. рис. 2 
Міжгрупові відмінності. Жінок із низькою І $\alpha$ п під час стискання та розтискання пальців кисті без зусилля характеризували відносно більші значення коефіцієнтів когерентності $\alpha 1-, \alpha 2-\mathrm{i}$ $\beta$-коливань у лобових ділянках (з $\mathrm{P}<0,05-<0,01$ ) (рис. 5). Натомість у центральних, задніх скроневих та тім'яних кортикальних ділянках установлено порівняно вищу когерентність частотних компонентів ЕЕГ у жінок із високою І $\alpha$ ( $\mathrm{P}<0,05-<0,01)$. Почергові рухи пальців та, особливо, рухи із силовим навантаженням супроводжувалися порівняно вищими значеннями когерентності у корі у жінок із високою $\mathrm{I \alpha Ч} \mathrm{(з} \mathrm{P}<0,05-<0,01)$ (рис. 5). В $\alpha 2$-субдіапазоні в цих умовах відзначали відносне переважання когерентності коливань у передніх кортикальних ділянках у жінок із низькою $\mathrm{I} \alpha$ Ч $(\mathrm{P}<0,05)$.

\section{Обговорення}

Відповідно до одержаних результатів установлено, що виконання МР, пов'язаних зі стисканням і розстиканням пальців кисті без зусилля, супроводжувалося збільшенням значень коефіцієнтів когерентності у корі. За даними Lurija (2000), це може бути пов'язане із функціональним об'єднанням кортикальних ділянок, задіяних під час керування рухами дистальних м'язів, із посиленням довільного контролю. Відповідно до даних Zhavoronkova (2007), така особливість в умовах виконання рухів субдомінантною рукою може мати компенсаторний характер і полегшувати поширення збудження між окремими ділянками кори. У жінок із низькою індивідуальною $\alpha$-частотою така закономірність мала більшу генералізованість і значущість у високих ( $\alpha 3-, \beta-)$ частотах спектра ЕЕГ, що може вказувати на більшу неспецифічність процесів кортикальної активації.

За виконання почергових рухів пальців і рухів із силовим навантаженням поряд із подібними змінами у жінок обох груп фіксували зменшення коефіцієнтів когерентності $\theta-, \alpha_{1}$ - і $\alpha_{3}$ активності, здебільшого у лобових відведеннях кори. За даними Klimesh et al. (2007), Lurija (2000), Buzsáki (2006), такі зміни у $\alpha_{1}$ - i $\theta$-субдіапазонах можуть бути наслідком актуалізації оперативної пам'яті під час утримання у фокусі уваги інформації про сенсорні стимули та здійснювані рухи, посилення процесів селективної уваги. Зменшення когерентності $\alpha_{3}$-активності у лобовій ділянці може відображати додаткове селективне гальмування механізмів сенсорного входу (Ioffe, 2003; Kostandov, 2013) під час моторного програмування. Установлену закономірність із функціональної точки зору можна розглядати, наприклад, як ЕЕГ-корелят процесу зіставлення аферентних інформаційних потоків про нові параметри роботи м'язів із низхідними впливами з боку фронтальної кори щодо попередньої моторної програми. Такі низхідні гальмівні впливи у процесі виконання мануальних рухів субдомінантною рукою загалом заважають моторному програмуванню (Ioffe, 2003), та, відповідно до результатів Kostandov (2013), у нашому експерименті можуть свідчити про певне зменшення пластичності процесів моторного програмування за виконання рухів складнішого характеру та необхідності дотримання заданого темпу. Виявлені зміни когерентності частотних компонентів ЕЕГ загалом можуть бути показником збільшення контролю 3 боку лобових структур за цих умов.

Варто зауважити як загальну тенденцію, що зміни кортикальної активності, встановлені за умови виконання різних рухів пальців субдомінантної руки, як от звичних хапальних рухів, почергових рухів та рухів із силовим навантаженням, як правило, відзначалися низькою специфічністю. Таку закономірність ми пояснюємо тим, що фактор виконання експериментальних тестів субдомінантною рукою, очевидно, мав вирішальне значення в характері організації мозкової активності, ніж сама специфіка мануальних рухів. На противагу, під час виконання рухів пальців ведучою (правою) рукою у жінок і чоловіків Morenko et al. (2013; 2014) Morenko (2016), Morenko and Korzgyk (2016) відмічали характерні зміни кортикальної активності залежно від специфіки організації мануальної моторики.
Аналіз міжгрупових відмінностей вказує, що жінок із низькою I $\alpha$ Ч характеризували відносно більші значення коефіцієнтів когерентності $\alpha_{1}-, \alpha_{2}$ - і $\beta$-коливань у лобових ділянках. Це може свідчити про активніше залучення префронтальної ділянки у процес моторного програмування у жінок із низькою I $\alpha$ та вищий рівень їх довільної уваги за цих умов (Posner et al., 2006; Sviderskaja, 2009). Натомість у центральних, задніх скроневих і тім'яних кортикальних ділянках установлено порівняно вищу когерентність частотних компонентів ЕЕГ у жінок із високою $\mathrm{I} \alpha$ Ч. Такі результати можуть бути пов'язані з меншим рівнем концентрації довільної уваги у жінок із високою І $\alpha$ під час моторного програмування на тлі можливо активнішого використання моторних програм-автоматизмів, вилучених зі слів пам'яті. Наше припущення узгоджується з інформацією Каzennikov (2009) про роль моторної кори в активації наявних нервових автоматизмів для виконання рухів. Почергові рухи пальців та, особливо, рухи із силовим навантаженням супроводжувалися порівняно вищими значеннями когерентності у корі у жінок із високою І $\alpha$ Ч. Відповідно до результатів Kiroj et al. (2010) порівняно нижча когерентність частот спектра ЕЕГ у жінок із низькою I $\alpha$ може бути зумовлена слабшими інтегративними можливостями кори, пов'язаними із взаємодією неокортикальних проекцій різних аналізаторних систем. Водночас, в $\alpha_{1}$ - і $\alpha_{2}$-субдіапазонах ЕЕГ за цих умов відзначали відносне переважання когерентності коливань у фронтальних кортикальних ділянках у жінок із низькою I $\alpha$ Ч.

Функціональний зміст таких міжгрупових відмінностей загалом відображає використання додаткових механізмів для досягнення результату та, як наслідок, певну надлишковість мозкових процесів (Kiroy and Belova, 2000) на тлі, можливо, слабших інтегративних можливостей кори у групі з низькою I $\alpha$ Ч.

\section{Висновки}

Виконання мануальних рухів субдомінантною рукою у відповідь на сенсорні сигнали в жінок із різними вихідними характеристиками $\alpha$-активності загалом супроводжувалося збільшенням когерентності частотних компонентів ЕЕГ, особливо в лобових, скроневих, центральних та тім'яних кортикальних ділянках. Поряд із тим, під час виконання почергових рухів пальців та рухів із силовим навантаженням у жінок обох груп фіксували зменшення коефіцієнтів когерентності $\theta-, \alpha_{1}$ - і $\alpha_{3}$ активності, здебільшого у лобових відведеннях кори. У жінок iз низькою $\mathrm{I} \alpha Ч$ реєстрували вищу когерентність частотних компонентів ЕЕГ у лобових кортикальних ділянках. Натомість у центральних, задніх скроневих та тім'яних відведеннях установлено порівняно вищу когерентність частотних компонентів ЕЕГ у жінок із високою І $\alpha$ Ч.

Зміни кортикальної активності, встановлені під час виконання різних рухів пальцями субдомінантної руки, як от звичних хапальних рухів, почергових рухів та рухів із силовим навантаженням, як правило, відзначалися низькою специфічністю. Таким чином, фактор виконання експериментальних тестів субдомінантною рукою, очевидно, мав вирішальне значення в характері організації мозкової активності, порівняно із самою специфікою мануальних рухів.

\section{Подяки}

Дослідження виконане в рамках наукової теми біологічного факультету Східноєвропейського національного університету імені Лесі Українки «Нейрофізіологічні механізми та системна організація сенсомоторної діяльності людини (віковий і статевий аспекти)», № 0111U002143 (2009-2011рр.).

\section{References}

Anderson, M. P., Mochizuki, T., Xie, J., Fischler, W., Manger, J. P., Talley, E. M., Scammell, T. E., \& Tonegawa, S. (2005). Thalamic Cav3.1 T-type $\mathrm{Ca}^{2+}$ 
channel plays a crucial role in stabilizing sleep. Proceedings of the National Academy of Sciences, 102(5), 1743-1748.

Angelakis, E., Lubar, J. F., Stathopoulou, S., \& Kounios, J. (2004). Peak alpha frequency: An electroencephalographic measure of cognitive preparedness. Clinical Neurophysiology, 115, 887-897.

Anokhin, A., Muller, V., Lindenberger, U., Heath, A. C., \& Myers, E. (2006). Genetic influences on dynamic complexity of brain oscillations. Neuroscience Letter, 397(1-2), 93-98.

Averbeck, B. B., Chafee, M. V., Crowe, D. A., \& Georgopoulos, A. P. (2002) Parallel processing of serial movements in prefrontal cortex. Proceedings of the Nation Academy of Sciences, 99(20), 13172.

Bazanova, O. M. (2008). Age related alpha activity change differs for males and females and for low and high alpha frequency EEG patterns. Revista Española de Neuropsicología, 10(1), 82-83.

Bellone, C., \& Nicoll, R. A. (2007). Rapid bidirectional switching of synaptic NMDA receptors. Neuron, 55(5), 779-788.

Buzsáki, G. (2006). Rhythms of the brain. Oxford University Press, New York.

Cisek, P. (2005). Neural representations of motor plans, desired trajectories, and controlled object. Cognitive Process, 6(1), 15-24.

Hikosaka, O., Nakamura, K., Saka, K., \& Nakahara, H. (2002). Central mechanisms of motor skill learning. Current Opinion in Neurobiology, 12(2), 217-222.

Hummel, F., Saur, R., Lasogga, S., Plewnia, C., Erb, M., Wildgruber, D., Grodd, W., \& Gerloff, C. (2004). To act or not to act: Neural correlates of executive control of learned motor behavior. NeuroImage, 23, 1391-1401.

Ioffe, M. (2003). Mozgovye mehanizmy formirovanija novyh dvizhenij pri obuchenii: Jevoljucija klassicheskih predstavlenij [Brain mechanisms of formation of new movements in the training: the evolution of classical concepts]. I. P. Pavlov Journal of Higher Nervous Activity, 53(1), 5-21 (in Russian).

Kaplan, A. J., \& Borisov, S. V. (2003). Dinamika segmentnih harakteristik al'fa-aktivnosti EEG cheloveka $\mathrm{v}$ pokoe i pri kognitivnyh nagruzkah [Dynamics segment characteristics of EEG alpha-activity of man at rest and during cognitive load]. I. P. Pavlov Journal of Higher Nervous Activity, 53(1), 22-32 (in Russian).

Kazennikov, O. V. (2009). Kortiko-spinal'nye vlijanija na distal'nye myshcy ruk pri inercionnoj nagruzke [Corticospinal effect on distal muscles of the hands when the inertial load]. I. P. Pavlov Journal of Higher Nervous Activity, 59(3), 288-295 (in Russian).

Kiroj, V. N., Vladimirskij, B. M., Aslanjan, E. V., Bahtin, O. M., \& Minjaeva, N. R. (2010). Jelektrograficheskie korreljaty real'nyh i myslennyh dvizhenij: Spektral'nyj analiz [Electrographic correlates of real and mental movements: Spectral analysis]. I. P. Pavlov Journal of Higher Nervous Activity, 60(5), 525-533 (in Russian).

Kiroy, V. N., \& Belova, E. I. (2000). Mechanisms of formation and role of the oscillatory activity of neuronal populations in brain state and information processing. I. P. Pavlov Journal of Higher Nervous Activity, 50(2), 179-191.

Klimesch, W., Sauseng, P., \& Hanslmayr, S. (2007). EEG alpha oscillations: The inhibition-timing hypothesis. Brain Research Reviews, 53, 63-88.

Kostandov, J. A. (2013). Izmenenija niz'ko- i vysokochastotnyh kolebanij al'fa-diapazona EEG $\mathrm{v}$ intervalah mezhdu znachimimi zritel'nym stimulami [Changes in the low- and high-frequency oscillations of EEG alpha range in the intervals between the significance of visual stimuli]. Human Phisiology, 39(4), 5-12 (in Russian).

Kristeva, R., Chakarov, V., Losch, F., Hummel, S., Popa, T., \& SchulteMönting, J. (2005). Electroencephalographic spectral power in writer's cramp patients: Evidence for motor cortex malfunctioning during the cramp. NeuroImage, 27(3), 706-714.

Lurija, A. R. (2000). Vysshie kortikal'nye funkcii cheloveka i ih narushenija pri lokal'nyh porazhenijah mozga [Higher cortical functions of man and their disturbances in local brain lesions]. Akademicheskij Prospekt, Moscow (in Russian).
Morenko, A. G., Kocan, I. J., \& Pavlovich, O. S. (2013). Kortikal'ni aktivacijni procesi u cholovikiv iz visokoju ta niz'koju vihidnoju individual'noju chastotoju al'fa-ritmu pid chas sensomotornoï dijal'nosti riznoji skladnosti. Fiziologichnij Zhurnal, 59(5), 41-49 (in Ukrainian).

Morenko, A. G., Tsjos, A. V., \& Kotsan, I. Y. (2014). Features of the cortical activity of men having a high or low alpha-frequency background of the EEG while performing alternate finger movements. Helth Problems of Civilization, 8(1), 24-31.

Morenko, A. G., Tsjos, A. V., \& Kotsan, I. Y. (2013). Electrical activity of the cerebral cortex in men having high or low output alpha-frequencies while performing usual manual movements in response to sensory signals. Human and Health, 7(3), 3-9.

Morenko, A. H. (2016). Bioelectrical activity of the brain during performance of manipulative movements in women with different modal alpha-frequencies. Visnyk of Dnipropetrovsk University. Biology, Medycyna, 7(1), 65-70.

Morenko, A. H., \& Korzgyk, O. V. (2016). Brain processes in women with different modal alpha-frequency through the execution of manual movements with applying of force. Biological Bulletin of Bogdan Chmelnitskiy Melitopol State Pedagogical University, 1, 326-341.

Müller, G. R., Neuper, C. Rupp, R., Keinrath, C., Gerner, H. J., \& Pfurtscheller, G. (2003). Event-related beta EEG changes during wrist movements induced by functional electrical stimulation of forearm muscles in man. Neuroscience Letters, 340(2), 143-147.

$\mathrm{Ng}, \mathrm{S}$. C., \& Raveendran, P. (2007). EEG peak alpha frequency as an indicator for physical fatigue. Medicon, 16, 517-520.

Niswender, C. M., Jones, C. K., \& Conn, P. J. (2005). New therapeutic frontiers for metabotropic glutamate receptors. Current Topics in Medicinal Chemistry, 5(9), 847-857.

Page, A. J., O’Donnell, T. A., \& Blackshaw, L. A. (2006). Inhibition of mechanosensitivity in visceral primary afferents by $\mathrm{GABA}(\mathrm{B})$ receptors involves calcium and potassium channels. Neuroscience, 137(2), 627-636.

Posner, M. I., Sheese, B. E., Oldudas, Y., \& Tang, Y. (2006). Analyzing and shaping human attentional networks. Neural Networks, 19, 1422.

Razumnikova, O. M., Tarasova, I. V., \& Vol'f, N. V. (2009). Osobennosti aktivacii kory u lic s vysokoj i nizkoj verbal'noj kreativnost'ju: Analiz al'fa 1-, 2-ritmov [Features activation in persons with peak and off-peak times verbal kreatyvity: Analysis of alpha 1-, 2-rythm]. I. P. Pavlov Journal of Higher Nervous Activity, 59(5), 581-586 (in Russian)

Ruge, D., Muggleton, N. Hoad, D., Caronni, A., \& Rothwell, J. C.(2014). An unavoidable modulation? Sensory attention and human primary motor cortex excitability. European Journal of Neuroscience, 40(5), 2850-2858.

Smit, C. M., Wright, M. J., Hansell, N. K., Geffen, G. M., \& Martin, N. G. (2006). Genetic variation of individual alpha frequency (IAF) and alpha power in a large adolescent twin sample. International Journal of Psychophysiology, 61(2), 235-243.

Spergel, D. J. (2007). Calcium and small-conductance calcium-activated potassium channels in gonadotropin-releasing hormone neurons before, during, and after puberty. Journal of Endocrinology, 148(5), 2383-2390.

Sviderskaja, N. E. (2009). Formy funkcional'noj asimmetrii prostranstvennoj organizacii fonovih EEG u cheloveka [The forms of functional asymmetry of the spatial organization of the background EEG in humans]. I. P. Pavlov Journal of Higher Nervous Activity, 59(1), 66-74 (in Russian).

Umrjuhin, E. A., Korobejnikova, I. I., \& Karatygin, N. A. (2009). Uspeshnost' vypolnenija testovyh zadanij studentami s razlichnymi spektral'nym harakteristikami $\alpha$-ritma fonovoj jelektrojencefalogrammy [Successful execution of tests students with different spectral characteristics $\alpha$-EEG background rhythm]. Human Phisiology, 35(5), 33-39 (in Russian).

Zhavoronkova, L. A. (2009). Pravshi-levshi. Mezhpolusharnaja asimmetrija biopotencialov mozga cheloveka [Right-handed people, the left-hander. Hemispheric asymmetry of the human brain biopotentials]. Jekoinvest, Krasnodar (in Russian). 